\title{
EFFECTS OF CONSERVATION AGRICULTURE ON PRODUCTIVITY AND ECONOMICS OF MAIZE-WHEAT BASED CROPPING SYSTEMS IN MID-WESTERN NEPAL
}

\author{
K. Pariyar ${ }^{1 *}$, A. Chaudhary ${ }^{2}$, P. Sapkota ${ }^{3}$, S. Sharma ${ }^{2}$, C.B. Rana ${ }^{2}$, J. Shrestha ${ }^{4}$ \\ ${ }^{1}$ Ministry of Agriculture and Livestock Development, Nepal \\ ${ }^{2}$ Horticulture Research Station, Dailekh, Nepal \\ ${ }^{3}$ Texas Tech University, Lubbock, USA \\ ${ }^{4}$ Agriculture Botany Division, NARC, Khumaltar, Lalitpur, Nepal.
}

\begin{abstract}
The effects of two tillage methods (zero tillage and conventional tillage), two residue managements (residue kept and residue removed) and two levels of cropping system (maize + soybean and sole maize) were studied over 3 years (2015-2017) at Dailekh district of Nepal. Arun-2 and Puja were the varieties of maize and soybean used respectively, followed by winter wheat. The results revealed that the maize + soybean system had significantly higher plant population and ear population (34.83 thousands ha ${ }^{-1}$ and 34.35 thousands $\mathrm{ha}^{-1}$, respectively), grains per row (37.1), ear length $(16.6 \mathrm{~cm})$ and $20.5 \%$ higher grain yield as compared to sole maize. The highest maize equivalent yield $\left(7.92 \mathrm{t} \mathrm{ha}^{-1}\right)$ was recorded in maize + soybean as compared to the lower grain yield equivalent $\left(7.06 \mathrm{t} \mathrm{ha}^{-1}\right)$ in sole maize. Zero tillage accounted relatively higher benefits (high net income and $\mathrm{B}: \mathrm{C}$ ratio) as compared to conventional tillage. The residue kept plot resulted significantly higher $\mathrm{B}: \mathrm{C}$ ratio $(2.41)$ than the residue removed (2.11) and the maize + soybean recorded $82.5 \%$ greater B:C ratio compared to sole maize. Net annual income was significantly higher in zero tillage, residue kept and maize + soybean system (NRs. 223072.00, 222958.00 and 269016.00 ha $^{-1}$ respectively). Such combinations are recommended for Dailekh district of Nepal to have profitable crop productivity.
\end{abstract}

Keywords: Intercropping, Maize, Residue, Soybean, Tillage

\section{INTRODUCTION}

Maize is one of the major food crops and main source of livelihood and income in Nepal, which contributes about $6.54 \%$ of the gross agricultural domestic product (AGDP) and $3.15 \%$ of the gross domestic product (GDP) (MoAD, 2013). Maize is extensively grown in the mid-hills of Nepal and it was usually cultivated as sole crop

\footnotetext{
* Corresponding author: keyrun1991@gmail.com
} 
from decades. In Nepal, after rice, maize occupies the second place in terms of cultivated area (891583 ha) and production (2231517 ton) (MoAD, 2016) which plays an important role in national food security. However, area and production of maize is in declining trend annually, which might be due to the negative impact of climate change, poor soil nutrient and water availability to the plant. A novel management system needs to be promoted and adopted to address these issues. Furthermore, conservation agriculture (CA) which is characterized by minimum tillage with previous crop residue retention can be the most suitable approach to enhance prevailing agricultural system of mid-hills of Nepal.

The declining trend of crop productivity might be due to application of poor technologies and use of obsolete genotypes along with higher cost of production, which has been exacerbated by the shortage of labor in agriculture (Joshi et al., 2012). Increased numbers of plowing and furrowing have caused higher soil erosion and nutrition loss, resulting to further degradation of agricultural land (Gardener and Gerrard, 2003; Acharya et al., 2007). High rate of soil erosion is one of the major causes for low yields of maize, a major staple for poor farmers in hill region (Tiwari et al., 2004). Furthermore, Rijal (2001) reported soil erosion, poor retention of organic matter, and unbalanced fertilization as main reasons for declining soil fertility in mid-hills of Nepal. Thus, high erosion and reduced application of organic matter have caused reduction of soil fertility resulting lesser productivity and sustainability of the system. There is an insistent need to introduce better technologies to stimulate sustainable agriculture along with conservation of land resources. Katuwal et al. (2017) concluded that no-till, residue retention and incorporation, strip cropping, intercropping and systematic crop rotation along with the inclusion of legumes and introduction of improved varieties are the potential areas of CA in hills. Despite of being a potential technology to solve such problems, evaluations of CA systems have been rarely documented. Therefore, the goal of this study was to evaluate implications of CA systems on crop productivity and financial benefits of maize-based farming system in the mid-hill region of Nepal.

\section{METHODOLOGY}

The experiment was conducted at research blocks of Horticultural Research Station, Dailekh, Nepal $\left(28^{\circ} 85^{\prime} \mathrm{N}, 81^{\circ} 72 \mathrm{E}, 1300\right.$ meter above sea level) during summer season of three consecutive years: 2015, 2016 and 2017. The separate research plots were allocated for the three years such that only a maize-wheat cropping pattern was followed, leaving the land to be fallow in the other seasons of a year.

The experiment was laid out in a split-split plot design with eight treatments and three replications in each year. The treatment consisted two methods of tillage (zero tillage and conventional tillage) as the whole plot, two different levels of residue management (residue kept and residue removed) as sub-plot and two different levels of intercropping namely maize + soybean and sole maize as sub-sub plot. Land was 
prepared following the two different methods (zero and conventional tillage). Firstly, preceding wheat was harvested and crop stubbles were cleaned out with no any tillage operation for zero tillage plots. Secondly, tillage operations were carried out three times by a tractor driven cultivator followed by leveling of surface for the conventional tillage plots. Residue of wheat straw was applied @ $10 \mathrm{mt} \mathrm{ha}^{-1}$ as a crop residue of preceding cropping season in case of residue management system. Arun-2 variety of maize and Puja variety of soybean were used in the study.

Each of the plots was maintained at $15 \mathrm{~m}^{2}$ size having the length of $5 \mathrm{~m}$ length and 3 $\mathrm{m}$ width. Row to row spacing for maize crop in each plot was maintained at $100 \mathrm{~cm}$ with $50 \mathrm{~cm}$ spacing between plants maintaining two plants per hill in the individual plot. The seed of maize was sown using Zab-planter. Besides, soybean was intercropped between two maize rows with the spacing of $50 \mathrm{~cm}$ between the soybean rows and $10 \mathrm{~cm}$ between the plants of the row. The harvest area used for yield measurement for maize and soybean was $15 \mathrm{~m}^{2}$ and $12 \mathrm{~m}^{2}$ respectively. Furthermore, total of 8 rows of soybean were established between 5 rows of maize in a plot of intercropping. Total amount of fertilizers applied for maize was @ 120:60:40 NPK kg ha ${ }^{-1}$ and $10 \mathrm{mt}$ FYM ha ${ }^{-1}$, wherein the $50 \%\left(60 \mathrm{~kg} \mathrm{ha}^{-1}\right.$ urea) of the recommended dose of $\mathrm{N}$ and full dose of $\mathrm{P}$ and $\mathrm{K}$ were applied during the land preparation and the rest $50 \% \mathrm{~N}$ was applied in two splits- $25 \%$ during knee height stage and $25 \%$ during silking stage. Similarly, the separate dose of fertilizer was applied for soybean @30:40:30 kg NPK ha ${ }^{-1}$ and 6 mt FYM ha ${ }^{-1}$. Weeds were controlled using glyphosate during land preparation. In case of zero tillage, weeds in the standing crop were controlled using post emergence herbicide; 2, 4-D @ of 0.5$0.8 \mathrm{~kg} \mathrm{ha}^{-1}$. Similarly, manual weeding was done during the knee height stage of maize for conventional tillage.

The data on traits such as plant and ear height, plant, and ear population, grains per row, rows per ear, and ear length were recorded at the time of harvesting, taking five sample plant of each plot and averaged finally. Further, cobs were harvested, husks were removed and five sample cobs of each genotype were weighed and averaged and the final grain yield was calculated after sun-drying and moisture content measuring $12 \%$. Also, the soybean yield was measured. The maize stover and soybean straw was weighed lastly after drying.

The total cost for different operations based on treatments was accounted. The gross income from each operation in terms of NRs. per hectare was calculated. The net income was calculated as- Net Income $=$ Gross income - Total cost; B: $\mathrm{C}$ ratio $=$ Gross income/Total cost and Harvest index $(\mathrm{HI})=$ Economic yield/Biological yield . Where, the economic yield is the sum of grain yield of maize and seed yield of soybean. Biological yield includes the grain and stover yield of maize plus seed and stover yield of soybean.

The data were analyzed using GenStat Package. 
Pariyar et al.

\section{RESULTS AND DISCUSSION}

\section{Biometric observations of maize plant and ear height}

The effect of tillage and residue management on plant height and ear height of maize was found to be non-significant. However, the effect of intercropping on plant and ear height of maize was noticed with significant effect (Table 1). Maize and soybean intercropping showed the tallest plant $(219.8 \mathrm{~cm})$ and the maximum ear height $(109.8$ $\mathrm{cm})$ whereas the shortest plant $(212.2 \mathrm{~cm})$ and minimum ear height $(101.3 \mathrm{~cm})$ was measured on sole maize. The average plant height and ear height of maize was measured to be $216.0 \mathrm{~cm}$ and $105.5 \mathrm{~cm}$ respectively. Similar findings on effect of intercropping on maize height were recorded by Hamd et al. (2014). Likewise, relatively taller plants measured due CT in comparison to $\mathrm{ZT}$ in our research is in accordance with the findings of Iqbal et al. (2013), who had also recorded shorter plants in ZT in comparison to CT. However, several past research findings have found that the maize plants are not always shorter in no-tillage (Zero tillage) systems (Imholte and Carter, 1987). The plant height explains the ear height and they are generally correlated.

\section{Yield attributing characters of maize}

This experiment revealed significant variation in plant population, ear population, grains per row, and rows per ear due to effect of intercropping. However, nonsignificant effect of tillage and residue management was recorded for this study. Similarly, this study revealed significant variation in ear length due to effect of residue management and intercropping.

\section{Plant population and ear population}

Significant variation of plant population and ear population was revealed due to the effect of intercropping (Table 1). The overall plant stand (34.83 thousands ha $\left.^{-1}\right)$ and ear population ( 34.35 thousands $\mathrm{ha}^{-1}$ ) was found maximum in intercropping system as compared to the least plant stand (33.00 thousands $\mathrm{ha}^{-1}$ ) and minimal ear population (31.39 thousands $\mathrm{ha}^{-1}$ ) in the sole maize plots. Similarly, average plant and ear population recorded were 33.92 thousands $\mathrm{ha}^{-1}$ and 32.87 thousands $\mathrm{ha}^{-1}$ respectively. 
Table 1. Effects of tillage, residue management, and intercropping on plant and ear height along with plant and ear population of maize

\begin{tabular}{|c|c|c|c|c|}
\hline Treatments & $\begin{array}{l}\text { Plant height } \\
\quad(\mathrm{cm})\end{array}$ & $\begin{array}{c}\text { Ear height } \\
(\mathrm{cm})\end{array}$ & 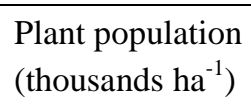 & 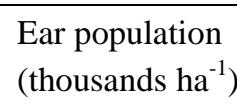 \\
\hline \multicolumn{5}{|c|}{ Tillage } \\
\hline ZT & 213.8 & 102.3 & 33.37 & 31.74 \\
\hline $\mathrm{CT}$ & 218.1 & 108.8 & 34.46 & 34.00 \\
\hline $\operatorname{SEm}( \pm)$ & 4.06 & 3.67 & 1.077 & 0.909 \\
\hline $\operatorname{LSD}_{(0.05)}$ & Ns & Ns & Ns & Ns \\
\hline \multicolumn{5}{|c|}{ Residue management } \\
\hline Residue kept & 216.4 & 106.9 & 32.94 & 32.94 \\
\hline $\begin{array}{l}\text { Residue } \\
\text { removed }\end{array}$ & 215.5 & 104.1 & 34.89 & 32.80 \\
\hline $\operatorname{SEm}( \pm)$ & 3.4 & 2.19 & 0.745 & 0.822 \\
\hline $\operatorname{LSD}_{(0.05)}$ & Ns & Ns & Ns & Ns \\
\hline \multicolumn{5}{|c|}{ Cropping system } \\
\hline$(\mathrm{M}+\mathrm{S})-\mathrm{W}$ & 219.8 & 109.8 & 34.83 & 34.35 \\
\hline Ms-W & 212.2 & 101.3 & 33.00 & 31.39 \\
\hline $\operatorname{SEm}( \pm)$ & 2.05 & 1.69 & 0.529 & 0.529 \\
\hline $\operatorname{LSD}_{(0.05)}$ & $5.91^{*}$ & $4.87 * *$ & $1.523^{*}$ & $0.529 * *$ \\
\hline $\mathrm{CV}(\%)$ & 5.7 & 9.6 & 9.4 & 9.6 \\
\hline Grand mean & 216.0 & 105.5 & 33.92 & 32.87 \\
\hline
\end{tabular}

Note: $\mathrm{ZT}=\mathrm{Zero}$ tillage, $\mathrm{CT}=$ Conventional tillage, $(\mathrm{M}+\mathrm{S})-\mathrm{W}=$ Maize and soybean intercrop followed by wheat, Ms-W=Maize sole followed by wheat, SEm=Standard Error of Means, LSD=Least Significance Difference, $\mathrm{CV}=$ Coefficient of variation. Ns, $*$ and $* *$ indicate Non-significance, significance, and highly significance at $\mathrm{P}<0.05$ and $\mathrm{P}<0.01$ respectively.

\section{Grains per row}

There is significant variation in number of grains per row (GPR) from 35.3 to 37.1 in MS-W and $(\mathrm{M}+\mathrm{S})-\mathrm{W}$ respectively due to effect of intercropping (Table 2). However, there is non-significant effect in grains per row due to tillage and residue management.

\section{Rows per ear}

There is no effect of tillage, residue management and intercropping in number of rows per ear as elucidated in the presented table. Furthermore, maximum number of rows per ear (12.6) was recorded with $(\mathrm{M}+\mathrm{S})-\mathrm{W}$ (Table 2). 


\section{Ear length}

Both the treatment factors: residue levels and intercropping had significant effect on the ear length except for the tillage (Table 2). Ear length was recorded to be maximum $(16.8 \mathrm{~cm})$ in residue kept plots, however, shortest ear length $(15.9 \mathrm{~cm})$ was found in residue removed plots. Likewise, significantly the longest ear $(16.6 \mathrm{~cm})$ was measured in the $(\mathrm{M}+\mathrm{S})-\mathrm{W}$ as compared to shortest ear $(16.0 \mathrm{~cm})$ in $\mathrm{Ms}-\mathrm{W}$. The mean ear length measured was $16.3 \mathrm{~cm}$.

Table 2. Effect of tillage, residue management, and intercropping on the grains per row, rows per ear and ear length of maize

\begin{tabular}{lcccc}
\hline \multicolumn{1}{c}{ Treatments } & Grains per row & Rows per ear & Ear length $(\mathrm{cm})$ \\
\hline Tillage & \multicolumn{3}{c}{} \\
\hline ZT & 36.0 & 12.3 & 16.4 \\
CT & 36.4 & 12.6 & 16.3 \\
SEm $( \pm)$ & 0.353 & 0.1242 & 0.231 \\
LSD $(0.05)$ & $\mathrm{Ns}$ & $\mathrm{Ns}$ & $\mathrm{Ns}$ \\
\hline \multicolumn{4}{c}{ Residue management } \\
\hline Residue kept & 36.8 & 12.4 & 16.8 \\
Residue removed & 35.5 & 12.5 & 15.9 \\
SEm $( \pm)$ & 0.603 & 0.178 & 0.283 \\
LSD $(0.05)$ & $\mathrm{Ns}$ & $\mathrm{Ns}$ & $0.6^{* *}$ \\
\hline \multicolumn{4}{c}{ Cropping system } & 16.6 \\
\hline M+S)-W & 37.1 & 12.6 & 16.0 \\
Ms-W & 35.3 & 12.4 & 0.285 \\
SEm $( \pm)$ & 0.499 & 0.1277 & $0.58^{*}$ \\
LSD $(0.05)$ & $1.436^{*}$ & $\mathrm{Ns}$ & 7.4 \\
CV $(\%)$ & 8.3 & 6.1 & 16.3 \\
\hline Grand mean & 36.2 & 12.481 & \\
\hline
\end{tabular}

Note: $\mathrm{ZT}=$ Zero tillage, $\mathrm{CT}=$ Conventional tillage, $(\mathrm{M}+\mathrm{S})-\mathrm{W}=$ Maize and soybean intercrop followed by wheat, Ms-W=Maize sole followed by wheat, SEm=Standard Error of Means, LSD=Least Significance Difference, $\mathrm{CV}=$ Coefficient of variation, Ns, * and $* *$ indicate Non-significance, significance, and highly significance at $\mathrm{P}<0.05$ and $\mathrm{P}<0.01$ respectively.

\section{Yield parameters}

There was a significant effect of tillage on the stover yield, however the tillage effect was non-significant on the yield of maize, soybean, soybean straw and harvest index. The stover and soybean yield significantly varied due to residue management. 


\section{Maize yield}

The tillage system and residue levels had no significant effect on the grain yield of maize (Table 3). This is in conformity with the findings of Kapusta et al. (1996), who reported no significant difference in grain yield of maize with no tillage and conventional tillage over the time. Furthermore, this might be due to no significant difference in plant population in both systems. However, the $(\mathrm{M}+\mathrm{S})-\mathrm{W}$ system revealed highly significant effect on the maize yield with $20.5 \%$ more yield of maize in comparison with the sole maize. Likewise, the highest grain yield of $(\mathrm{M}+\mathrm{S})-\mathrm{W}$ as compared to $\mathrm{Ms}-\mathrm{W}$ might be due to the highest values for number of ear length, number of rows/ear, and number of grains/row which was also mentioned by Hamid et al. (2014). Furthermore, the highest plant population (Abuzar et al., 2011) and maximum kernel rows per ear (Emam, 2001; Pariyar et al., 2018) might have contributed to the maximum maize yield. The mean maize yield was recorded to be $4.3 \mathrm{tha}^{-1}$.

\section{Stover yield}

The tillage system showed insignificant effects on the stover yield (Table 3). However, the residue level and intercropping revealed statistically significant effect on stover yield with the maximum stover yield of $6.3 \mathrm{tha}^{-1}$ and $6 / 2 \mathrm{tha}^{-1}$ respectively. However, the minimum stover yield of $4.8 \mathrm{t} \mathrm{ha}^{-1}$ and $4.9 \mathrm{t} \mathrm{ha}^{-1}$ was recorded due to effect of residue levels and intercropping system respectively. The mean stover yield of the experiment was found to be $5.4 \mathrm{t} \mathrm{ha}^{-1}$.

\section{Seed and stover yield of soybean}

The effects of tillage systems, residue levels and intercropping were found highly significant on soybean yield (Table 3 ). The soybean yield from zero tillage was significantly maximum $\left(0.8 \mathrm{tha}^{-1}\right)$ as compared to that of conventional tillage $(0.7 \mathrm{t}$ $\left.\mathrm{ha}^{-1}\right)$.The residue kept plots recorded the significantly highest $\left(0.8 \mathrm{t} \mathrm{ha}^{-1}\right)$ soybean yield as compared to residue removed plots $\left(0.7 \mathrm{t} \mathrm{ha}^{-1}\right)$. Similarly, the soybean yield was found significantly highest in the maize + soybean system which was more than $100 \%$ in comparison to mean soybean yield. Further, tillage and residue management did not show significant effect on soybean stover yield. The intercropped plot showed considerably higher soybean stover yield $\left(3.3 \mathrm{t} \mathrm{ha}^{-1}\right)$.

\section{Harvest Index (HI)}

The effects of tillage system and residue levels observed non-significant effect in partitioning economic yield and biological yield, also known as Harvest Index (Table $3)$. However, intercropping has effect on harvest index with highly significance showing the maximum HI (0.41) in Ms-W in comparison to (M+S)-W system (0.40). Undie et al. (2012) reported similar findings with significantly high $\mathrm{HI}$ in sole maize than any other intercropping arrangements. Similarly, lesser HI in intercropping maize with soybean as compared to sole maize was recorded by Ahmad et al. (2016). Thus, the reduced production of maize biomass in intercropping with soybean as compared to sole maize might be due to the direct competition between them for different plant growth factors like moisture, nutrient, space, light, etc. The average HI of the experiment was recorded as 0.40 . 


\section{Maize equivalent yield}

The effect of tillage systems and residue management on the maize equivalent yield was found to be non-significant, though the effect of intercropping has highly significant effect. Considerably, the higher maize grain yield equivalent $\left(7.92 \mathrm{t} \mathrm{ha}^{-1}\right)$ was obtained in $(\mathrm{M}+\mathrm{S})-\mathrm{W}$ as compared to the lower grain yield equivalent $\left(7.06 \mathrm{t} \mathrm{ha}^{-}\right.$ ${ }^{1}$ ) in Ms-W. This was due to the higher grain yield and existing market price of component soybean (Rs. 80 per $\mathrm{kg}$ ), while the existing market price of maize grain was Rs. 25 per kg. Similarly, it was recorded to be higher in all cases of intercropping with respect to pure stand yield of maize as mentioned by Kheroar and Patra (2013).The mean maize equivalent yield, however, was recorded to be $7.49 \mathrm{t} \mathrm{ha}^{-1}$.

Table 3. Effects of tillage, residue management, and intercropping on the grains per row, rows per ear and ear length of maize

\begin{tabular}{|c|c|c|c|c|c|c|}
\hline \multirow[t]{2}{*}{ Treatments } & \multicolumn{2}{|c|}{ Maize } & \multicolumn{2}{|c|}{ Soybean } & \multirow{2}{*}{$\begin{array}{c}\text { Harvest } \\
\text { Index (HI) }\end{array}$} & \multirow{2}{*}{$\begin{array}{c}\text { Maize equivalent } \\
\text { yield }\left(\text { tha }^{-1}\right)\end{array}$} \\
\hline & $\begin{array}{c}\text { Grain } \\
\text { yield } \\
\left(\text { tha }^{-1}\right)\end{array}$ & $\begin{array}{l}\text { Stover } \\
\text { yield } \\
\left(\text { tha }^{-1}\right)\end{array}$ & $\begin{array}{l}\text { Seed yield } \\
\quad\left(\mathrm{tha}^{-1}\right)\end{array}$ & $\begin{array}{l}\text { Stover yield } \\
\quad\left(\text { tha }^{-1}\right)\end{array}$ & & \\
\hline \multicolumn{7}{|c|}{ Tillage } \\
\hline ZT & 4.1 & 5.8 & 0.8 & 1.6 & 0.40 & 7.37 \\
\hline $\mathrm{CT}$ & 4.4 & 5.7 & 0.7 & 1.7 & 0.41 & 7.61 \\
\hline $\operatorname{SEm}( \pm)$ & 0.096 & 0.133 & 0.038 & 0.1624 & 0.0089 & 0.097 \\
\hline $\operatorname{LSD}(0.05)$ & Ns & Ns & $0.1238 * *$ & Ns & Ns & Ns \\
\hline \multicolumn{7}{|c|}{ Residue management } \\
\hline Residue kept & 4.4 & 6.3 & 0.8 & 1.6 & 0.40 & 7.61 \\
\hline $\begin{array}{l}\text { Residue } \\
\text { removed }\end{array}$ & 4.1 & 5.2 & 0.7 & 1.7 & 0.41 & 7.37 \\
\hline $\operatorname{SEm}( \pm)$ & 0.104 & 0.140 & 0.028 & 0.091 & 0.010 & 0.104 \\
\hline $\operatorname{LSD}(0.05)$ & Ns & $0.4^{* *}$ & $0.1 * *$ & Ns & Ns & Ns \\
\hline \multicolumn{7}{|c|}{ Intercropping } \\
\hline$(\mathrm{M}+\mathrm{S})-\mathrm{W}$ & 4.7 & 6.2 & 1.5 & 3.3 & 0.40 & 7.92 \\
\hline Ms-W & 3.9 & 5.3 & 0 & 0 & 0.41 & 7.06 \\
\hline $\operatorname{SEm}( \pm)$ & 0.098 & 0.141 & 0.038 & 0.109 & 0.0061 & 0.979 \\
\hline $\operatorname{LSD}(0.05)$ & $0.3 * *$ & $0.4 * *$ & $0.1 * *$ & $0.3 * *$ & $0.02 * *$ & $0.28 * *$ \\
\hline $\mathrm{CV}(\%)$ & 13.8 & 14.8 & 30.5 & 39.3 & 8.9 & 7.8 \\
\hline Grand mean & 4.3 & 5.7 & 0.8 & 1.7 & 0.40 & 7.49 \\
\hline
\end{tabular}

Note: $\mathrm{ZT}=$ Zero tillage, $\mathrm{CT}=\mathrm{Conventional} \mathrm{tillage,}(\mathrm{M}+\mathrm{S})-\mathrm{W}=$ Maize and soybean intercrop followed by wheat, Ms$\mathrm{W}=$ Maize sole followed by wheat, SEm=Standard Error of Means, LSD=Least Significance Difference, $\mathrm{CV}=$ Coefficient of variation, $\mathrm{Ns}, *$ and $* *$ indicate Non-significance, significance, and highly significance at $\mathrm{P}<0.05$ and $\mathrm{P}<0.01$ respectively. 


\section{Economics of maize}

\section{Gross Income and Net Income for Maize}

The Gross Income and Net Income from tillage system was observed with nonsignificant effect whereas, the residue levels and intercropping practices showed highly significant effect on them respectively (Table 4). The gross income was relatively greater in ZT (NRs. 1,74,211 ha ${ }^{-1}$ ) as compared to CT (NRs. 1,73,227 ha ${ }^{-1}$ ). Due to residue management, the significantly highest gross income (NRs. 1,83,477 $\mathrm{ha}^{-1}$ ) and net income (NRs. 1,17,699 $\mathrm{ha}^{-1}$ ) was calculated on residue kept when compared with the residue removed plots (NRs. 1,63,961 and NRs. 96,949 ha $^{-1}$ respectively). The maximum gross income and net income in the residue kept plots was due to the deduction of labor cost for removal of residue kept field. Goverdhanrao and Ramana (2017) and Sime (2015) also explained the better economic response of $\mathrm{ZT}$ in maize based cultivation practices.

Similarly, (M+S)-W system yields maximum gross income (NRs. 2,40,385 ha ${ }^{-1}$ ) and net income (NRs. 1,66,971 $\mathrm{ha}^{-1}$ ) as compared to that from Ms-W (NRs. 1,07,053 per ha and NRs. 47,677 ha- ${ }^{-1}$ respectively). The higher gross and net return of maize from $(\mathrm{M}+\mathrm{S})-\mathrm{W}$ system might be due to higher land, soil and resource use, higher total yield of maize and soybean and higher marketing price of soybean. This result was in agreement with the report of Verma et al. (1997) who explained the higher net income in all intercropping systems in comparison to pure or sole cropping.

\section{B:C Ratio}

The economic analysis using $\mathrm{B}: \mathrm{C}$ ratio showed non-significant effect of the tillage system (Table 4). However, relatively higher B:C ratio resulted from zero tillage (2.32) as compared to conventional tillage (2.20). This inferred that ZT was more profitable than the $\mathrm{CT}$ and the profitability of ZT was mainly due to the less cost of production and higher gross income. Kumari and Sudheer (2016) explained the highest $\mathrm{B}: \mathrm{C}$ ratio of $\mathrm{ZT}$ in comparison to farmers practice.

The applied residue level and intercropping system showed highly remarkable effect on the B:C ratio. Residue kept on the plots showed significantly higher ratio (2.41) as compared to residue removed operation (2.11) because of reduction of labor cost to remove the residue and the gross income was also high from the residue kept plot. $(\mathrm{M}+\mathrm{S})-\mathrm{W}$ recorded significantly highest B:C ratio (2.92) when compared with Ms-W (1.60). 
Table 4. Effect of tillage, residue management, and intercropping on the total cost, gross income, net income and $\mathrm{B}: \mathrm{C}$ ratio from maize

\begin{tabular}{|c|c|c|c|c|}
\hline Times & MTC (NRs. ha ${ }^{-1}$ ) & MGI (NRs. ha- ${ }^{-1}$ ) & MNI (NRs. ha- ${ }^{-1}$ ) & $\begin{array}{l}\mathrm{B}: \mathrm{C} \\
\text { Ratio }\end{array}$ \\
\hline \multicolumn{5}{|c|}{ Tillage } \\
\hline $\mathrm{ZT}$ & 71687 & 174211 & 109751 & 2.32 \\
\hline $\mathrm{CT}$ & 76751 & 173227 & 104897 & 2.20 \\
\hline $\operatorname{SEm}( \pm)$ & 273.6 & 3847.8 & 4253.4 & 0.0612 \\
\hline $\operatorname{LSD}(0.05)$ & $892.2 * *$ & Ns & Ns & Ns \\
\hline \multicolumn{5}{|c|}{ Residue management } \\
\hline Residue kept & 73293 & 183477 & 117699 & 2.41 \\
\hline Residue removed & 75145 & 163961 & 96949 & 2.11 \\
\hline $\operatorname{SEm}( \pm)$ & 464 & 3588.7 & 3519.2 & 0.0547 \\
\hline $\operatorname{LSD}(0.05)$ & $1391 *$ & $10759.0^{* *}$ & $10550.6^{* *}$ & $0.1485 * *$ \\
\hline \multicolumn{5}{|c|}{ Intercropping } \\
\hline$(\mathrm{M}+\mathrm{S})-\mathrm{W}$ & 82172 & 240385 & 166971 & 2.92 \\
\hline Ms-W & 66266 & 107053 & 47677 & 1.60 \\
\hline $\operatorname{SEm}( \pm)$ & 164.5 & 4240 & 4156.7 & 0.0562 \\
\hline $\operatorname{LSD}(0.05)$ & $473.7 * *$ & $12213.9 * *$ & $11974.0 * *$ & $0.1618^{* *}$ \\
\hline $\mathrm{CV}(\%)$ & 1.3 & 14.6 & 23.2 & 14.9 \\
\hline Grand mean & 74219 & 173719 & 107324 & 2.26 \\
\hline
\end{tabular}

Note: ZT=Zero tillage, $\mathrm{CT}=$ Conventional tillage, $(\mathrm{M}+\mathrm{S})-\mathrm{W}=$ Maize and soybean intercrop followed by wheat, Ms-W=Maize sole followed by wheat, SEm=Standard Error of Means, LSD=Least Significance Difference, $\mathrm{CV}=$ Coefficient of variation, $\mathrm{MTC}=$ Maize Total Cost, MGI= Maize Gross Income and MNI= Maize Net Income. Ns, * and ** indicate Non-significance, significance, and highly significance at $\mathrm{P}<0.05$ and $\mathrm{P}<0.01$ respectively.

\section{Economics of cropping system}

\section{System's Gross Income}

Tillage has no significant effect on Gross Income. However, the residue levels affected with high significance showing maximum returns in residue kept (NRs. 3,73,011 ha ${ }^{-1}$ ). Similarly, the cropping system showed significantly highest gross income in $(\mathrm{M}+\mathrm{S})-\mathrm{W}$ system (NRs. 4,28,507 ha ${ }^{-1}$ ) with mean SGI of NRs. $354917 \mathrm{ha}^{-1}$.

\section{System's Net Income}

Different tillage and residue levels and the cropping system had highly considerable influence in the net income of whole system. The Net Income of ZT was significantly highest than that of CT by $21.6 \%$. Similarly, the residue kept recorded considerably 
highest income (NRs. 2,22,958 $\mathrm{ha}^{-1}$ ) as compared to that of residue removed (NRs. $\left.1,83,530 \mathrm{ha}^{-1}\right)$. Also, the $(\mathrm{M}+\mathrm{S})-\mathrm{W}$ was more profitable with maximum income by NRs. 1,31,544 $\mathrm{ha}^{-1}$ as compared to that of Ms-W. The mean SNI was calculated to be NRs. 2,03,244 ha- ${ }^{-1}$ Table 5, Fig. 1).

Table 5. Effect of tillage, residue management, and intercropping on the total cost, gross income, and net income of the conservation agriculture system

\begin{tabular}{|c|c|c|c|}
\hline Treatments & SGI (NRs. ha ${ }^{-1}$ ) & STC (NRs. ha ${ }^{-1}$ ) & SNI (NRs. ha ${ }^{-1}$ ) \\
\hline \multicolumn{4}{|c|}{ Tillage } \\
\hline ZT & 363210 & 140138 & 223072 \\
\hline $\mathrm{CT}$ & 346625 & 163209 & 183416 \\
\hline $\operatorname{SEm}( \pm)$ & 7099.4 & 753.7 & 7115.2 \\
\hline $\operatorname{LSD}(0.05)$ & Ns & $2458 * *$ & $23204 * *$ \\
\hline \multicolumn{4}{|c|}{ Residue Management } \\
\hline Residue kept & 373011 & 150053 & 222958 \\
\hline Residue Removed & 336824 & 153294 & 183530 \\
\hline $\operatorname{SEm}( \pm)$ & 4961.7 & 438.2 & 4982.6 \\
\hline $\operatorname{LSD}(0.05)$ & $14875 * *$ & $1314 * *$ & $14938 * *$ \\
\hline \multicolumn{4}{|c|}{ Cropping system } \\
\hline$(\mathrm{M}+\mathrm{S})-\mathrm{W}$ & 428507 & 159491 & 269016 \\
\hline Ms-W & 281328 & 143856 & 137472 \\
\hline $\operatorname{SEm}( \pm)$ & 5502.4 & 168.9 & 5486 \\
\hline $\operatorname{LSD}(0.05)$ & $15851 * *$ & $4867 * *$ & $15803 * *$ \\
\hline $\mathrm{CV}(\%)$ & 9.3 & 0.7 & 16.2 \\
\hline Grand Mean & 354917 & 151674 & 203244 \\
\hline
\end{tabular}

Note: $\mathrm{ZT}=\mathrm{Zero}$ tillage, $\mathrm{CT}=$ Conventional tillage, $(\mathrm{M}+\mathrm{S})-\mathrm{W}=$ Maize and soybean intercrop followed by wheat, Ms-W=Maize sole followed by wheat, SEm=Standard Error of Means, LSD=Least Significance Difference, $\mathrm{CV}=$ Coefficient of variation, $\mathrm{STC}=$ System Total Cost, SGI= System Gross Income and $\mathrm{SNI}=$ System Net Income. Ns and ** indicate Non-significance and highly significance at $\mathrm{P}>0.05$ and $\mathrm{P}<0.01$ respectively. 


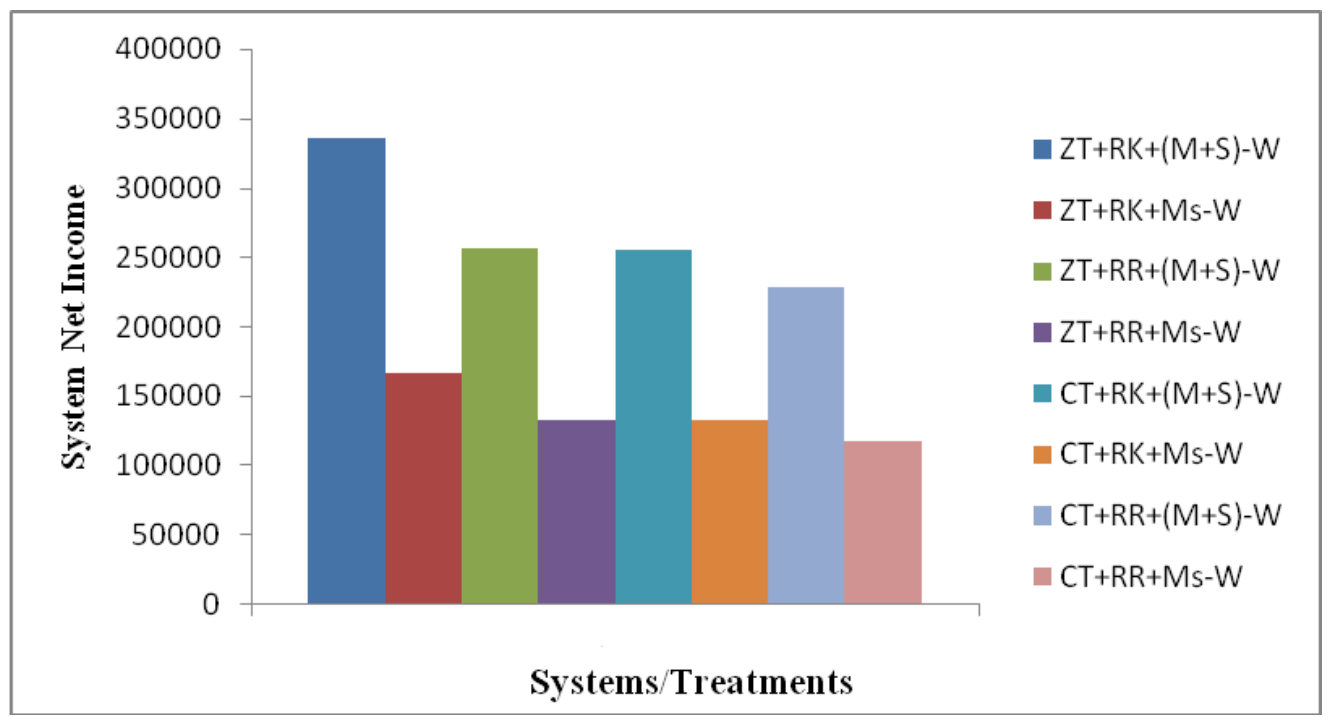

Fig. 1 Graph showing system net income in a year over different systems

\section{Systems yield:}

Table 6. Effect of tillage, residue management, and intercropping of system yield

\begin{tabular}{l|c}
\hline Treatments & System yield $\left(\right.$ tha $\left.^{-1}\right)$ \\
\hline ZT+RK+(M+S)-W & 10.8 \\
ZT+RK+Ms-W & 7.7 \\
ZT+RR+(M+S)-W & 9.3 \\
ZT+RR+Ms-W & 6.5 \\
CT+RK+(M+S)-W & 9.7 \\
CT+RK+Ms-W & 7.5 \\
CT+RR+(M+S)-W & 9.5 \\
\hline CT+RR+Ms-W & 7.3 \\
\hline SEm ( $)$ & 0.2789 \\
LSD $(0.05)$ & $0.8^{* *}$ \\
CV $(\%)$ & 8.5 \\
\hline
\end{tabular}

Note: $\mathrm{ZT}=$ Zero tillage, $\mathrm{CT}=$ Conventional tillage, $\mathrm{RR}=$ Residue removed, $\mathrm{RK}=$ Residue kept, Ms=Maize as sole crop, $(\mathrm{M}+\mathrm{S})-\mathrm{W}=$ Maize and soybean intercrop followed by wheat, Ms-W=Maize sole followed by wheat, SEm=Standard Error of Means, LSD=Least Significance Difference, CV=Coefficient of variation and "**” signifies highly significant at $\mathrm{P}<0.01$ 
System's yield was calculated by adding all the yield of maize, soybean and wheat obtained from the research trial and averaged over years. Analysis of variance of systems yield revealed the significant effect due to the application of several treatments. $\mathrm{ZT}+\mathrm{RK}+(\mathrm{M}+\mathrm{S})-\mathrm{W}$ showed highly significant system yield $\left(10.8 \mathrm{t} \mathrm{ha}{ }^{-1}\right)$ which was considerably followed by $\mathrm{CT}+\mathrm{RK}+(\mathrm{M}+\mathrm{S})-\mathrm{W}\left(9.7 \mathrm{tha}^{-1}\right), \mathrm{CT}+\mathrm{RK}+\mathrm{Ms}-\mathrm{W}$ $\left(9.5 \mathrm{t} \mathrm{ha}^{-1}\right)$ and $\mathrm{ZT}+\mathrm{RR}+(\mathrm{M}+\mathrm{S})-\mathrm{W}\left(9.3 \mathrm{t} \mathrm{ha}^{-1}\right)$ respectively. The similar result with highest system yield in $\mathrm{ZT}+\mathrm{RK}+(\mathrm{M}+\mathrm{S})-\mathrm{W}$ was found by Karki et al. (2014). The minimum system yield was found in $\mathrm{ZT}+\mathrm{RR}+\mathrm{Ms}-\mathrm{W}\left(6.5 \mathrm{t} \mathrm{ha}^{-1}\right)$, (Table.6).

\section{CONCLUSION}

The total cost of tillage operation was found significantly cheaper in case of zero tillage, with higher net income and greater benefit cost ratio. Thus, zero tillage was determined to be profitable over conventional tillage for Dailekh district. The tillage and residue management has no short term effect on the yield benefits of maize and soybean. Since, the overall system showed the maximum net income in ZT, RK and $(\mathrm{M}+\mathrm{S})-\mathrm{W}$, the conservation agriculture technology based on maize with the combination of $\mathrm{ZT}, \mathrm{RK}$ and $(\mathrm{M}+\mathrm{S})-\mathrm{W}$ is recommended for higher crop yield and better economic return in the condition of Dailekh district.

\section{ACKNOLEDGEMENTS}

The authors would like to thank Nepal Agricultural Research Council (NARC) for providing financial support and the National Maize Research Program, Chitwan for supply of the inputs and other logistics to carry out this research.

\section{REFERENCES}

Abuzar, M.R., Sadozai, G.U., Baloch, M.S., Baloch, A.A., Shah, I.H., Javaid, T., and Hussain, N. (2011). Effect of plant population densities on yield of maize. Journal of Animal and Plant Sciences, 21(4): 692-695.

Acharya, G., McDonald, M., Tripathi, B., Gardner, R., and Mawdesley, K. (2007). Nutrient losses from rain-fed bench terraced cultivation systems in high rainfall areas of the mid-hills of Nepal. Land Degradation \& Development, 18: 486-499.

Ahmad, A., Wahid, M.A., Fazal, M.W., Anees, M.U., Arshad, M.A., and Saeed, M.T. (2016). Agro-Economic Assessment of Maize-Soybean Intercropping System. AmericanEurasian Journal of Agricultural \& Environmental Sciences, 16 (11): 1719-1725.

Emam, Y. (2001). Sensitivity of grain yield components to plant population density in nonprolific maize (Zea mays L.) hybrids. Indian Journal of Agricultural Science, 71(6): 367-370.

Gardner, R., and Gerrard, A. (2003). Runoff and soil erosion on cultivated rain-fed terraces in the Middle Hills of Nepal. Applied Geography, 23: 23-45. 
Govardhanrao, V., and Venkata, R.P. (2017). Economic Performance of Zero Tillage Technology in Maize under Agency Tracts of Andhra Pradesh. Asian Journal of Agricultural Extension, Economics \& Sociology, 16(4), ISSN: 2320-7027.

Hamd, W.A., Shalaby, E.M., Dawood, R.A., and Zohry, A.A. (2014). Effect of Cowpea (Vigna sinensis L.) with Maize (Zea mays L.) Intercropping on Yield and Its Components. International Journal of Agricultural and Biosystems Engineering, Vol:8, No:11.

Imholte, A.A., and Carter, P.R. (1987). Planting date and tillage effects breakage susceptibility at later planting dates and with on corn following corn. Agronomy Journal, 79:746-751.

Joshi, K.D., Conry, C., and Witcombe, J.R. (2012). Agriculture, seed and innovation in Nepal: Industry and policy issues for the future. Project Paper. International Food Policy Research Institute. Retrieved July 15, 2018 from www.ipfri.org.

Kapusta, G., Krausz, R.F., and Matthews, J.L. (1996). Corn yield is equal in conventional, reduced and no tillage after 20 years. Agronomy Journal, 88: 812-817.

Karki, T.B., Gadal, N., and Shrestha, J. (2014). Systems optimization through tillage and residue management and cropping system in maize based system. International Journal of Current Microbiology and Applied Sciences, 3(10): 990-1002.

Katuwal,Y. (2017). Conservation Agriculture in Nepal. Retrieved July 18, 2018 from https://www.linkedin.com/pulse/conservation-agriculture-nepal-yogendra-katuwal

Kheror, S., and Patra, B.C. (2013). Advantages of Maize-Legume Intercropping Systems. Journal of Agricultural Science and Technology. B3: 733-744.

Kumari, R.C., and Sudheer, J.M. (2016). On farm demonstration of zero tillage maize in farmers fields of Anantapuram district of Andhra Pradesh. International Journal of Agricultual Sciences, 12 (1) : 134-138.

MoAD. (2013). Statistical information on Nepalese agriculture, Government of Nepal. Ministry of Agriculture and Development, Agribusiness Promotion and Statistics Division, Singha Durbar, Kathmandu, Nepal.

MoAD. (2016). Statistical information on Nepalese agriculture, Government of Nepal. Ministry of Agriculture and Development, Agribusiness Promotion and Statistics Division, Singha Durbar, Kathmandu, Nepal.

Pariyar, K., Sapkota, P., Panta, S., Buda, P., and Karki, T.B. (2018). Performance and variation in phenotypic characters of maize genotypes in mid-western region of Nepal. International Journal of Agriculture, Environment and Food Sciences, 2(3): 109-103.

Rijal, S.P. (2001). Soil Fertility Decline in Nepal: Problem and strategy. Nepal Journal of Science and Technology, (3): 41-46.

Sime, G., Aune, B., and Mohammed H. (2015). Agronomic and economic response of tillage and water conservation management in maize, central rift valley in Ethiopia. Soil and Tillage Research, 148: 20-30

Tiwari, T.P., Brook, R., and Sinclair, F. (2004). Implications of hill farmers' agronomic practices in Nepal for crop improvement in maize. Experimental Agriculture, 40: 397417. 
Undie, U.L., Uwah, D.F., and Atto, E.E. (2012). Effect of Intercropping and Crop Arrangement on Yield and Productivity of Late Season Maize/Soybean Mixtures in the Humid Environment of South Southern Nigeria. Journal of Agricultural Science, 4(4), ISSN 1916-9752.

Verma, U.N., Pal, S.K., Singh, M.K., and Thakur, R. (1997). Productivity, energetic and competition function of wheat plus Indian mustard intercropping under varying fertilizer level. Indian Journal of Agronomy, 42: 201-204. 